\begin{tabular}{|c|c|c|c|c|}
\hline Cuadernos de Investigación Geográfica & 2001 & N$^{\circ} 27$ & pp. 7-16 & ISSN 0211-6820 \\
\hline
\end{tabular}

(C) Universidad de La Rioja

\title{
WATER RESOURCES AND ENVIRONMENTAL CHANGE IN SPAIN. A KEY ISSUE FOR SUSTAINABLE INTEGRATED CATCHMENT MANAGEMENT
}

FRANCESC GALLART PILAR LLORENS

Institute of Earth Sciences 'Jaume Almera'(CSIC), Lluís Solé i Sabarís, s/n 08028-Barcelona, Spain. fgallart@ija.csic.es, pllorens@ija.csic.es.

ABSTRACT: There are many evidences of water resources diminution in different parts of Spain for the period 1921-99, representing in average a $0.4 \%$ per year. This diminution has been claimed to be the result of the increasing irrigation and the climate variability. The main land use and cover change in Spanish mountain areas has been, since the middle of the $X X$ century, the afforestation subsequent to land abandonment, both spon taneous and supported by Spanish and European policies. The causal links between the increase in forest land cover and decrease in water yield have been largely demonstrated at the experimental catchment scale, although there is less evidence of these links at the operational scale.

The analysis of the water balance of several Spanish catchments during the last 50 years, showed that the main part of the observed decreases in flow are not explained by increases in water consumption by irrigation or by climate variability, but should be attributed to a change in the response of the headwaters. The relationships between change in forest cover and water flow decrease for these catchments were found similar to the relationships described elsewhere as experimental results. The management of land cover should be therefore taken into account for a true integrated catchment management.

RESUMEN: Existen muchas evidencias de que los recursos hídricos están disminuyendo en diferentes partes de España en el periodo 19211999, representando en promedio un $0.4 \%$ anual. Se ha afirmado que tal disminución es el resultado de un aumento del regadio y de la variabilidad climática. El principal cambio de uso del suelo y cubierta vegetal en las montañas españolas ha sido, desde mediados del siglo XX, la reforestación consiguiente al abandono de tierras de cultivo. La relación causal entre aumento de cubierta forestal y disminución de la producción de agua se ha demostrado a escala de cuenca experimental, aunque existen menos evi dencias a escala operacional.

El análisis del balance hídrico en varias cuencas españolas durante los últimos 50 años demuestra que la mayor parte de las disminuciones de caudal no se explican por el aumento del consumo de agua por el regadío 
o por la variabilidad climática, sino que debe atribuirse a un cambio de respuesta de las cabeceras fluviales. Las relaciones entre cambio en cubierta forestal y descenso de agua para estas cuencas son similares a las relaciones descritas en otros lugares a partir de resultados experimen tales. La gestión de la cubierta vegetal debería ser, por ello, tenida en cuenta para una gestión integrada de cuencas.

Key-words: Water resources, Plant cover, Land-use changes, Headwaters, Spain.

Palabras clave: Recursos hídricos, Cubierta vegetal, Cambios de uso del suelo, Cabeceras fluviales, España.

\section{Introduction.}

'Integrated catchment management' is easier said than done. Sometimes it is merely an offer-demand study that considers that the catchment is just a system of reservoirs, pipes and taps. Hydrology became just an appendix of applied statistics, evolving into a more sophisticated but scientifically empty information technology. An example of the need for integrative approaches may be taken from Spain.

In one hand, there are many evidences of water resources diminution in different Spanish catchments for the last 70 years, representing in average about $0.4 \%$. On the other hand, the main land use change observed in Spanish rural headwater areas is the afforestation of former agricultural lands. This process started in the first half of the XX century because of agricultural abandonment driven by socio-economic changes and Spanish policies. Recently, following the UE directives almost half of the surface reforested in Europe in the last years was in Spain (DGCONA, 2000). The finding of experimental hydrology obtained along the XX century clearly demonstrated that changes in land cover determine different water consumption in the catchments, and therefore changes in water resources (Bosch and Hewlett, 1982; Sahin and Hall, 1996). Nevertheless, since now water resources diminution has been analysed in Spain only as a result of increasing irrigation and climate variability (MIMAM 2000), but there is not discussion about the hydrological impact of land use and cover changes in headwater areas.

The aim of this paper is to perform a preliminary analysis of the relationships between land cover change and decrease in water flow in a sample of catchments in Spain. The ultimate purpose is not to obtain original scientific findings but to show the practical relevance of these facts, to stress the need of research in this field as well as to emphasise the importance of the management of land cover in headwater areas for a true catchment management.

\section{Land use and cover changes in Spain during the 20 century.}

Wide headwater areas in Spain suffered during the first three fourth parts of the 20 century the abandonment of farming and stockbreeding activities, linked to the loss of about $80 \%$ of the population (Lasanta, 1990). This process allowed the increase of forest- 
ed areas, both spontaneous and promoted by Spanish and EU Policies. In the period 1940-1982, nearly 3.2 million hectares were afforested in Spain, although the failure of some afforestation projects as well as wildfires counteracted part of this effort (Ortigosa, 1990). Subsequently, following UE directives, more than 400.000 ha have been reforested during the period 1994-98 (DGCONA, 2000). In the near future, national governments may be promoting the afforestation as a measure to counterbalance $\mathrm{CO}_{2}$ emissions, following the directions of the Kyoto protocol.

The assessment of land use changes reported by FAO (1990-1998) demonstrates an increase of forest and woodland area of $23 \%$ (6\% of the total area of Spain) during the period 1961-1998 (Figure 1). The increase of forest area was mainly produced at the expense of pasture area until 1985 and at the expense of the agricultural area afterwards, this change may be attributed to the incorporation of Spain in the European Union.

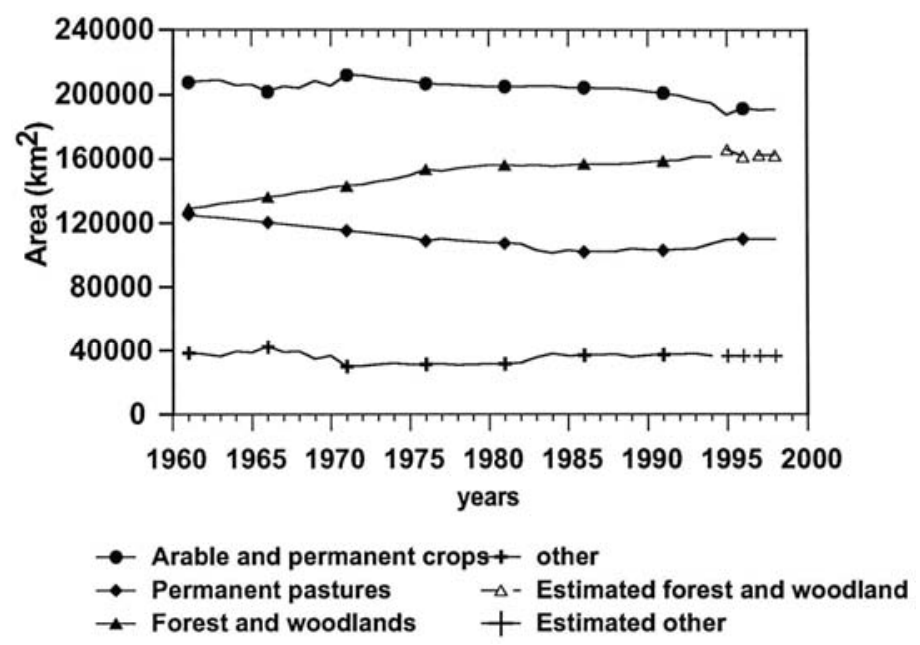

Figure 1. Evolution of land use in Spain for the period 1961-1998 (data from: FAO, 1990-98)

Nevertheless, this information gives an idea about the administrative changes rather than an assessment of land cover. The more detailed information on forest cover is provided by the first and second National Forest Inventories (MA,1968-1974; MAPA, 19901997) which, although were not synchronous for all the regions, give an idea of the changes in 20 years, between 1970 and 1990. A summary of the inventories (Figure 2) shows that the forest area was stable in the more humid autonomous regions, whereas it suffered relevant changes in the drier ones (Extremadura, Murcia). The overall forest area decreased in $9 \%$ of the total country area. On the other hand, the canopy cover fraction suffered an increase in all the Autonomous regions, with a mean change from 0.38 to 0.55 . This change must be considered as the result of the closure of clearings and vegetative growth of young forests recently overgrown or planted on former pasture and abandoned agricultural areas. 

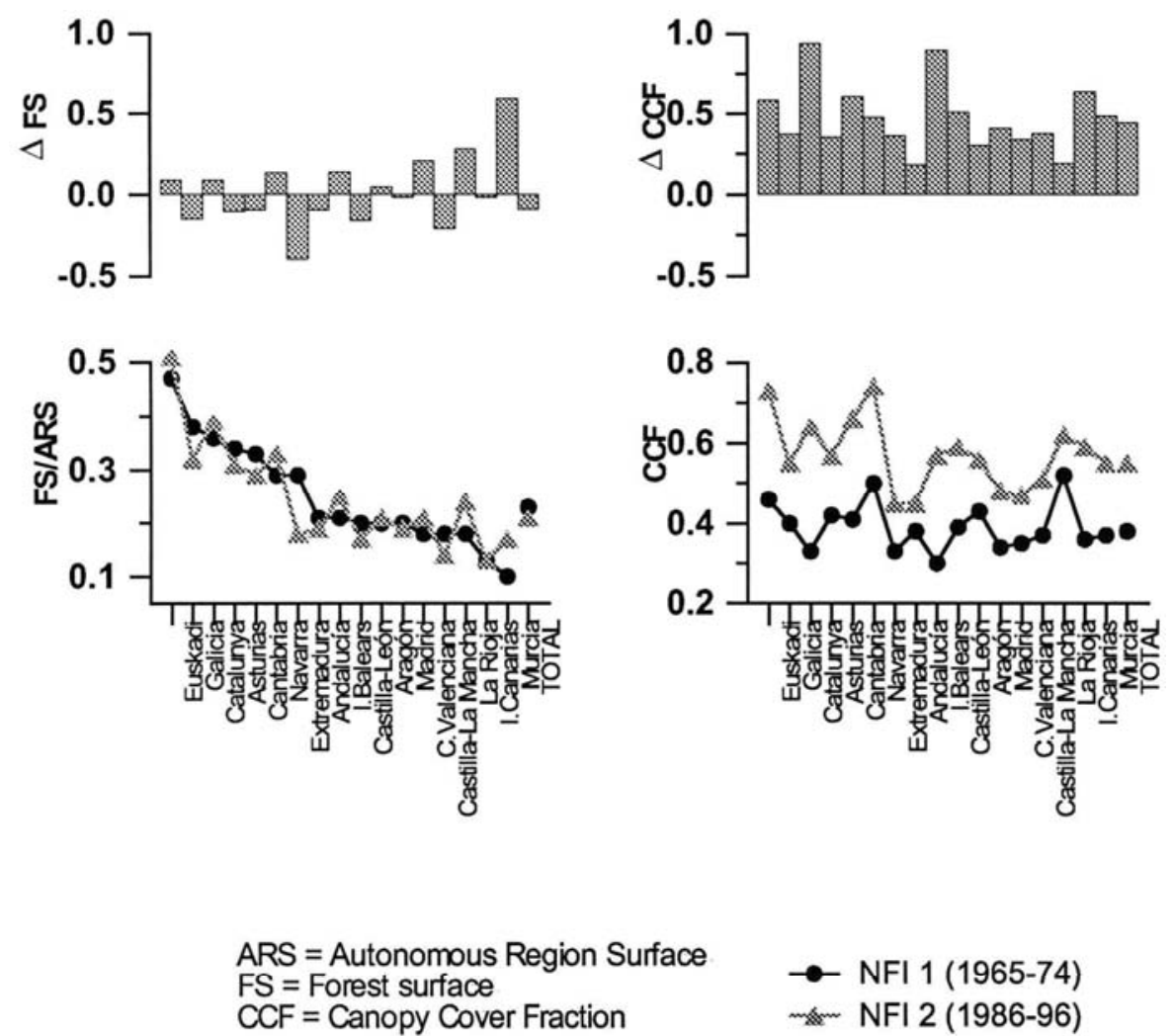

Figure 2. Differences in Forest Surface and Canopy Cover Fraction between the 1st and the 2nd 'Inventario Forestal Nacional'(Spanish national forest inventories. Data from: MA, 1968-1974 and MAPA, 1990-1997).

The relevance of land cover changes must be considered as the change in both forest area and canopy cover fraction. The product between forest area and canopy cover fraction (i.e., a measure of the area fully covered by the forest canopy) increased between the two inventories in $1,411,300$ ha ( $2.8 \%$ of the whole country surface). If this increase is divided by the canopy cover fraction obtained in the first inventory, the changes, expressed in terms of unchanging cover fraction, would represent an increase of $3,713,950 \mathrm{ha}$ ( $7.3 \%$ of the whole surface).

\section{Temporal evolution of water resources in Spain}

Most of the historical records of river discharges in Spain begun by 1940. Nowadays, after more than 50 years, decreasing trends of annual discharges have been observed by several authors in most of the flow records (Batalla et al., 1992; Vieira and Tavares, 1996; Prieto, 1996; MIMAM, 1998; MIMAM, 2000). The cause of these decreasing trends in flow have been attributed first to the increase in water abstractions, mainly for irrigation, 
and second to the climatic variability. A sample of the more relevant decreasing trends are shown on the Figures 3 to 5:

The record of the river Duero at Miranda (Figure 3) shows a decrease of $5,450 \mathrm{hm}^{3}$ $\mathrm{a}^{-1}$ (59\% of the mean flow) in the 62 years of the analysed period; the slope of the linear regression is significant at the 0.01 level in spite of the high inter-annual irregularity of the flow.

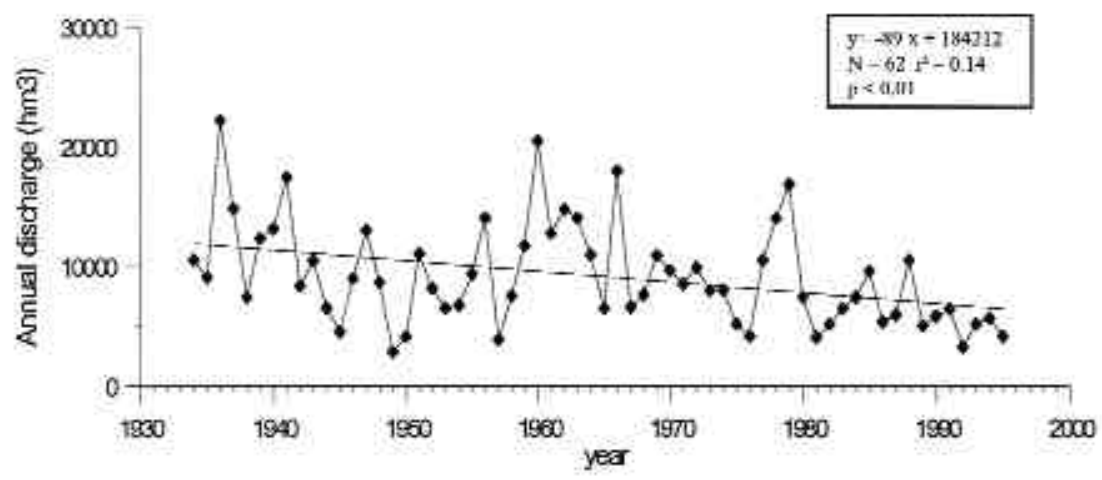

Figure 3. Annual observed discharge in the Duero river at Miranda (data from: Vieira and Tavares, 1996)

The annual flow record of the river Ebro at Tortosa (Figure 4) has been recently revised for the Spanish hydrological plan (MIMAM, 2000). The revised record has an increased temporal stability compared with the original record, but it still shows a decrease of $5760 \mathrm{hm}^{3} \mathrm{a}^{-1}$ (58.2\% of the mean flow) for the 57 years of the analysed period. As in the case of the former record, the slope of the linear regression is significant at the 0.01 level in spite of the high variability of the annual values.

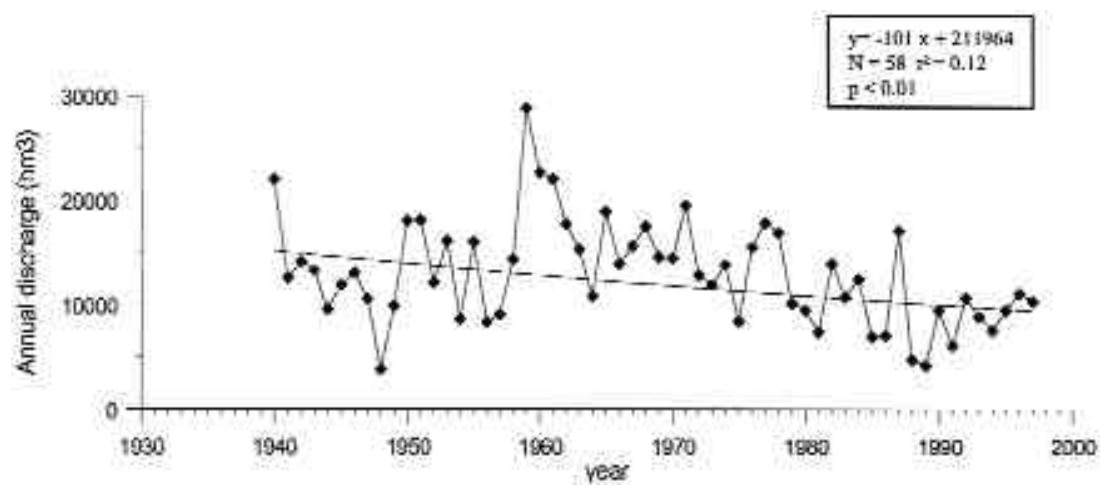

Figure 4. Annual observed discharge in the Ebro river at Tortosa (data from: MIMAM, 2000). 
Finally, the flow record of the Tagus river at the inlet of the Tajo-Segura transfer is shown on the Figure 5. This is a much smaller catchment but is analysed here because there has been no relevant increase of water use in the catchment and also because it provides water to the major infrastructure for water management in Spain. The record between 1912 and 1970 does not show any significant trend, but from 1940 to 1996 a decrease of $687 \mathrm{hm}^{3}$ $\mathrm{a}^{-1}$ (58\% of the mean flow) is observed, the slope of the linear regression being significant at the 0.01 level. It is important to mention that the Tajo-Segura transfer since its set-up in 1979 until 1997 was able to transfer only a mean of $263 \mathrm{hm}^{3} \mathrm{a}^{-1}$, whereas it was designed for $1000 \mathrm{hm}^{3} \mathrm{a}^{-1}$ and its demand was fixed in $600 \mathrm{hm}^{3} \mathrm{a}^{-1}$ (MIMAM, 1998).

The importance of these changes in the whole water resources in Spain has been attempted by Prieto (1966) using the records of a set of rivers representative of the several hydrological regions. This assessment suggests that the decrease represents about $33.7 \%$ of the mean flow in the period 1921-1995.

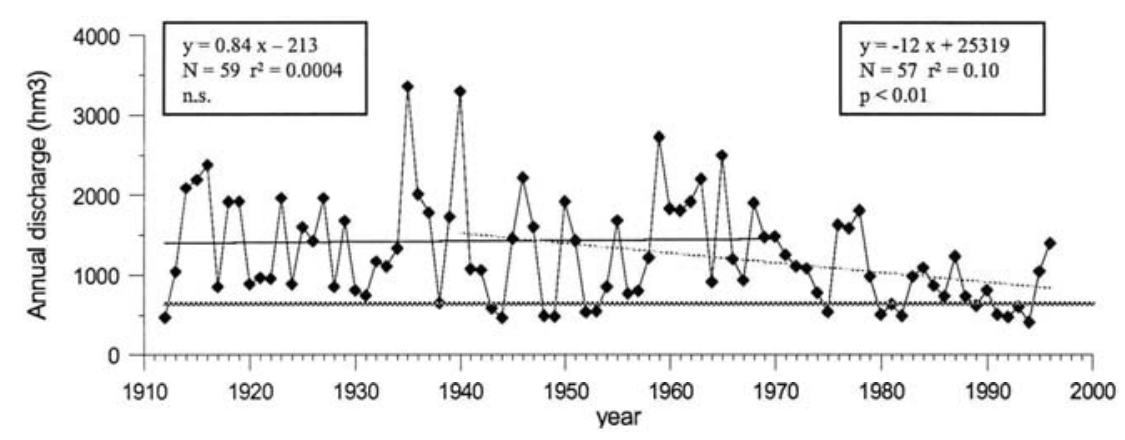

Figure 5. Annual observed discharge in the Tajo river at the Tajo-Segura inlet (data from MIMAM, 1998). The Thick grey line represents the demand of this infrastructure.

\section{Linking changes in land cover with trends in water resources.}

The Figure 6 represents the analysis of the changes in water balance of the Ebro river at Tortosa. The upper parts shows the observed flow as well as the flow simulated by MIMAM (2000) with a precipitation-runoff conceptual distributed model (Ruíz-García, 1999) which takes into account the evapotranspiration demand and uses the same catchment parameters for the whole analysed period. The temporal trend of the simulated flow is not significant but represents a decrease of $2,140 \mathrm{hm}^{3} \mathrm{a}^{-1}$ (16.6\% of the mean flow) than must be taken into account in the analysis. In the lower part, the evolution of water consumption for irrigation was assessed from the increase of irrigated areas estimated by MIMAM (2000) and the specific water consumption for crop irrigation (440 $\mathrm{mm} \mathrm{a}^{-1}$ ) assessed by Casterad and Herrero (1998). The water consumed by other kinds of uses 
was considered less than the return from irrigation. The temporal evolution of residuals (simulated flow minus observed flow minus water consumption) represented a decrease of water flow of $2,220 \mathrm{hm}^{3} \mathrm{a}^{-1}$ (17.2\% of the mean flow) for the studied period, and the slope of the linear regression was significant at the 0.01 level. The significant decrease of water flow not explained after the consideration of both the variability of climate and the evolution in water abstraction is to be considered the result of the increase of water consumption by the vegetation in the headwaters. Indeed, most of the records of the tributaries of the Ebro show decreasing trends at gauging points located before the derivations for irrigation (Gracia, 2000).

The same type of analysis was then performed in a simplified manner for the records of figures 3 and 5, as well as the Ebro at Palazuelos and Duero at Carrascal using data from Prieto (1996), the results being summarised on the Tab. 1. There are only relevant changes in water abstractions from the Duero river at both locations, where the amount of water consumed was estimated by applying a specific water consumption of $440 \mathrm{~mm}$ $\mathrm{a}^{-1}$ (Casterad and Herrero, 1998) to the new irrigated area (assuming an increase during the period of record of 55\% of the present irrigated area assessed by MIMAM, 2000). The changes in flow due to precipitation variation have been obtained since Prieto (1996) for the Duero at Carrascal, since Mestre (1996) for the Duero at Miranda and Ebro at
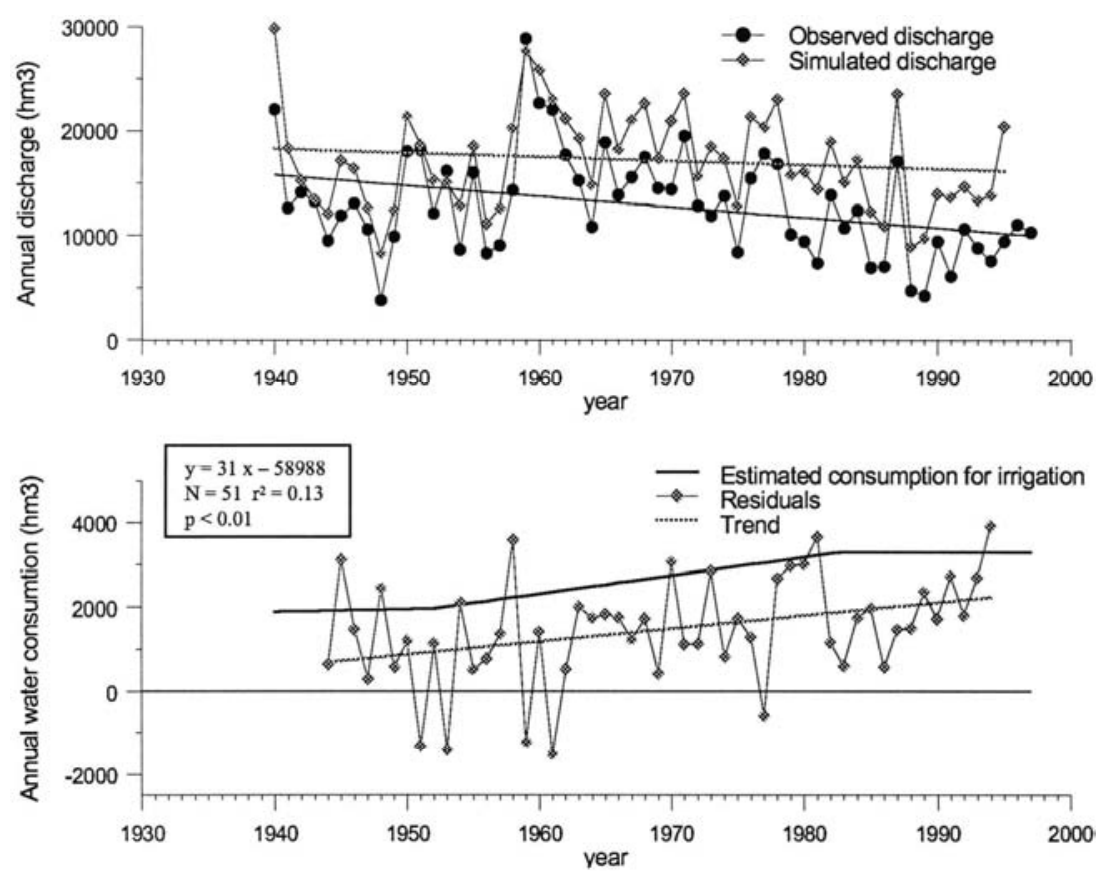

Figure 6. Above: Flow observed and simulated with a precipitation-runoff model in the Ebro river at Tortosa (both since MIMAM, 2000). Below: Estimated water consumption for irrigation and residuals (see text). 
Table 1. Breakdown of temporal changes in flow for a sample of rivers.

\begin{tabular}{|c|c|c|c|c|c|c|c|c|c|c|}
\hline river and location & $\begin{array}{l}\text { period } \\
\text { (years) }\end{array}$ & $\begin{array}{c}\text { flow } \\
(\text { hm } 3 a-1)\end{array}$ & $\begin{array}{c}\text { gross d } \\
(\mathrm{hm} 3 \mathrm{a}-1\end{array}$ & $\begin{array}{l}\text { crease } \\
)(\%)\end{array}$ & $\begin{array}{r}\text { consum } \\
(\text { hm } 3 a-1)\end{array}$ & $\begin{array}{r}\text { ption } \\
(\%) \\
\end{array}$ & $\begin{array}{r}\text { precipit } \\
(h m 3 a-1)\end{array}$ & $\begin{array}{l}\text { itation } \\
(\%) \\
\end{array}$ & $\begin{array}{r}\text { resid } \\
\text { (hm3 a-1 }\end{array}$ & $\begin{array}{l}\text { ual } \\
)(\%) \\
\end{array}$ \\
\hline Duero at Carrascal & $1921-95$ & 4440 & 1770 & 39.8 & 658 & 14.8 & 338 & 7.6 & 774 & 17.4 \\
\hline Duero at Miranda & $1934-96$ & 9190 & 5450 & 59.3 & 1080 & 11.8 & 1630 & 17.7 & 2740 & 29.8 \\
\hline Ebro at Palazuelos & $1915-95$ & 1670 & 619 & 37.1 & - & - & 112 & 6.7 & 507 & 30.4 \\
\hline Ebro at Tortosa & $1940-97$ & 12900 & 5760 & 44.7 & 1410 & 10.9 & 2140 & 16.6 & 2220 & 17.2 \\
\hline Tajo at T-S transfer & $1940-96$ & 1180 & 687 & 58.2 & - & - & 145 & 11.4 & 542 & 45.9 \\
\hline
\end{tabular}

Palazuelos, and since MIMAM (1998) for the Tagus catchment. The fact that catchments without relevant change in water consumption showed the higher range in residuals indicates that the consumption of water was not greatly underestimated in the other catchments. This preliminary assessment suggests that the residuals, i.e. the flow loss due to changes in the behaviour of headwaters, were more important than the flow loss due to either rainfall variability and increase of water consumption.

The residuals from the Table 1 were expressed in terms of runoff depth loss for a 20year period (assuming a linear change throughout the analysed period), and then compared with the respective increase of forest surface in terms of the canopy cover fraction in the first Forest Inventory. The results are shown on the Figure 7 together with other results obtained elsewhere for easier comparison. In this graph, the points with negative values in both coordinates (decreases in yield following augmentation in cover) are located together with points with both positive variables. This graph shows that the results obtained in this study were coherent with the results obtained elsewhere, although four of the cases suffered changes in forest cover smaller than or similar to the small range

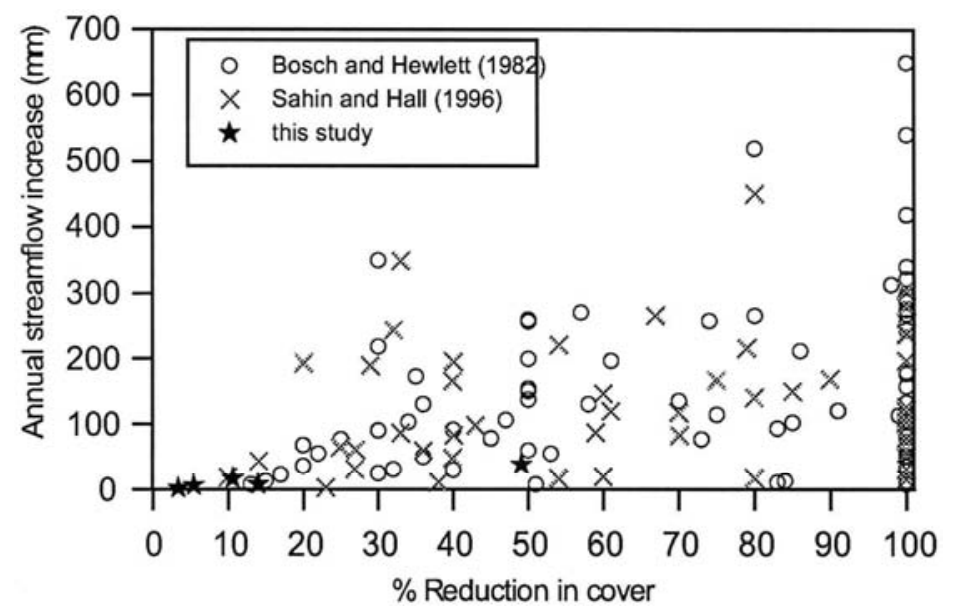

Figure 7. Relationship between changes in forest cover and water yield. Stars (that have negative values in both coordinate variables) represent the examples presented in table 1 are compared with cases reported elsewhere (Bosch and Hewlett, 1982. Sahin and Hall, 1996). 
reported in the literature. Furthermore, the size of the studied catchments are bigger than the cases reported in the literature.

\section{Conclusions}

Important changes in land cover in the headwater areas of Spain have occurred in the last 60 years, as a consequence of rural abandonment and environmental and agricultural policies. As afforestation is a slow process, for analysing land cover change it is necessary to consider not only the variation of forested areas extension, but also changes in canopy cover fraction. Detailed information available for analysing land cover change in Spain has a short time coverage (only 20 years).

Precipitation-runoff relationships are not stationary in most of Spanish catchments. Flow decrease was not only due to water abstractions for irrigation but mainly to the behaviour of headwaters, attributable to the increase in forest land cover. The hydrological consequences of these land use changes in headwaters seem therefore more important than precipitation trends and increase of water abstractions. Furthermore, these changes are already observable and are therefore more realistic than the predictable reduction of flow due to climatic change.

The preliminary results obtained suggest that the relationship between land cover change and flow decrease falls within the range reported in the literature, but the present case is related to larger catchments, analyses the afforestation process and includes smaller modifications of land cover.

More attention is therefore to be paid to both land cover changes in the headwaters and precipitation-rainfall relationships. In this study, large catchments have been studied in a preliminary manner in order to assess the economic and strategic impact of these changes. Nevertheless, the studies of scientific and applied value must be conducted in smaller catchments in order to consider more detailed characteristics of vegetation (density, type of trees, leaf area index...) and hydrometeorology (range of precipitation, role of snow, seasonal patterns...). The results of these studies would be of great value to assess the hydrological impact of land cover changes in the future or in other locations, to test and validate hydrological models, as well as to design hydrologically sound land management strategies to mitigate the effects of climate change.

The interdependence of water and land must be taken into account for true 'Integrated catchment management' at the operational scale. Non-irrigated rural areas (forests, rangelands and dry-farming areas) have also water requirements, directly taken from precipitation, that must also considered in the catchment water budget.

\section{Acknowledgements}

This work has been partly funded by the Secretaría de Estado de Aguas y Costas (Ministerio de Medio Ambiente, and the project EPROHIDRO (HID98-1056), of the Plan Nacional de Recursos Naturales, recursos hídricos 


\section{References}

Bosch, J.M. and Hewlett, J.D. (1982). A review of catchment experiments to determine the effect of vegetation changes on water yield and evapotranspiration. J. Hydrol., 55: $3-23$.

Casterad, M. A. and J. Herrero (1998). Irrivol: a method to estimate the yearly and montlhy water applied in an irrigation district. Water Resources Research, 34: 3045-3049.

DGCONA (2000). Estrategia Forestal Española. Ministerio de Medio Ambiente, Dirección General de Conservación de la Naturaleza, Madrid, 240pp.

FAO (1990-98): FAO Production Yearbook. FAOSTAT.

Gracia, J.J. (2000). La cuestión de los sobrantes del Ebro en el PHN. http://jaca.com/yesano/informes/informesobran/sobrantes.htm

Lasanta, T. (1990) Tendances actuelles de l'organisation spatiale des montagnes espagnoles. Annales de Géographie, 551: 51-71.

Mestre, A.(1996): Análisis de las series históricas de volúmenes de precipitación en las cuencas del Duero y el Ebro. $2^{\mathrm{a}}$ Conferencia Internacional de Hidrología Mediterránea. Los recursos hídricos en los países Mediterráneos. Iberdrola Instituto Tecnológico, Bilbao: 289-302.

MA (1968-1974) Primer inventario forestal de España. Ministerio de Agricultura, Dirección General de Montes, Caza y Pesca Fluvial, Madrid, 50v.

MAPA (1990-1997) Segundo inventario forestal nacional : 1986-1995. Ministerio de Agricultura, Pesca y Alimentación, Instituto Nacional para la Conservación de la Naturaleza, Madrid

MIMAM (1998). Libro Blanco del Agua en España. Ministerio de Medio Ambiente. Madrid, $855 \mathrm{pp}$.

MIMAM (2000). Plan Hidrológico Nacional. Análisis de los sistemas hidráulicos. Ministerio de Medio Ambiente, Madrid, 390 pp.

Ortigosa, L. (1990). Las repoblaciones forestales como estrategia pública de intervención en regiones degradadas de montaña. in: Geoecología de las áreas de montaña, Ed. J.M. García-Ruiz, Geoforma, Logroño, 297-311.

Prieto, C. (1996). La evolución de los recursos hídricos en España. $2^{\text {a }}$ Conferencia Internacional de Hidrología Mediterránea. Los recursos hídricos en los países Mediterráneos. Iberdrola Instituto Tecnológico, Bilbao, 257-288.

Ruiz-García, J.M. (1999). Modelo distribuido para la evaluación de recursos hídricos. Monografías del CEDEX, 67. Ministerio de Fomento, Madrid, 245 pp.

Sahin, V. \& Hall, M.J. (1996). The effects of afforestation and deforestation on water yields. J. Hydrol., 178: 293-309

Vieira, V. \& Tavares, MN. (1996). A brief statistical analysis of some Portuguese hydrologic data. $2^{\text {a }}$ Conferencia Internacional de Hidrología Mediterránea. Los recursos hídricos en los países Mediterráneos. Iberdrola Instituto Tecnológico, Bilbao, 227 254. 